(c) American Dairy Science Association, 2004.

\title{
Changes in the Proportions of Soluble and Insoluble Calcium During the Ripening of Cheddar Cheese
}

\author{
A. Hassan, ${ }^{1}$ M. E. Johnson, ${ }^{2}$ and J. A. Lucey ${ }^{1}$ \\ ${ }^{1}$ Department of Food Science, \\ ${ }^{2}$ Wisconsin Center for Dairy Research \\ University of Wisconsin-Madison, Madison 53706
}

\section{ABSTRACT}

In cheese, the concentration and form of residual $\mathrm{Ca}$ greatly influences texture. Two methods were used to determine the proportions of soluble (SOL) and insoluble (INSOL) Ca in Cheddar cheese during 4 mo of ripening. The first method was based on the acid-base buffering curves of cheese and the second was based on the extraction of the aqueous phase ("juice") of cheese under high pressure and determining the concentration of SOL Ca in the juice using atomic absorption spectroscopy. When cheese was acidified there was a strong buffering peak at $\mathrm{pH} \sim 4.8$, which was due to the solubilization of residual colloidal calcium phosphate (CCP) of milk that remained in cheese as INSOL Ca phosphate. The area of this buffering peak in cheese was expressed as a percentage of the original area of this peak in milk and was used to estimate the concentration of residual INSOL Ca phosphate in cheese. There were no significant differences between the 2 methods. The proportions of INSOL $\mathrm{Ca}$ in cheese decreased from $\sim 73$ to $\sim 58 \%$ between $\mathrm{d} 1$ and 4 mo. These methods will be useful techniques to study the role of $\mathrm{Ca}$ in cheese texture and functionality.

(Key words: calcium, colloidal calcium phosphate, milk salts, cheese functionality)

Abbreviation key: $\mathbf{C C P}=$ colloidal $\mathrm{Ca}$ phosphate, INSOL $=$ insoluble, SOL $=$ soluble.

\section{INTRODUCTION}

The mineral composition, especially the Ca concentration, is a well-known parameter that influences the textural and functional properties of cheese including hardness/firmness and melt/stretch (Lucey and Fox, 1993; Lucey et al., 2003). However, there is a close relationship between the rate of acid production, $\mathrm{pH}$ at

Received July 29, 2003.

Accepted October 6, 2003.

Corresponding author: J. A. Lucey; e-mail: jalucey@facstaff. wisc.edu. coagulant addition and whey drainage, and mineral content, all of which greatly influence the structure and texture of cheese. The effects of $\mathrm{pH}$ per se are often difficult to segregate from other concomitant changes, such as solubilization of colloidal calcium phosphate (CCP), changes in charge on the casein, and hydration of the casein molecules. Colloidal calcium phosphate has a crucial structural role in casein micelles, which is easily demonstrated since the removal of CCP results in the disintegration of the micelle during acidification at low temperatures. The interaction of $\mathrm{Ca}$ with the caseins has been reviewed extensively (Holt, 1992; Horne, 1998). Although there have been many studies on the solubilization of CCP in milk, much less is known about the degree of solubilization of CCP during cheese making and subsequent ripening.

There have been numerous studies concerning the impact of alterations in the cheese-making conditions (e.g., $\mathrm{pH}$ values at renneting, draining, or milling) on cheese composition and functional attributes. All of these modifications in the cheese-making protocol may change the concentration of residual $\mathrm{Ca}$ in cheese. It is well known that lower total Ca levels in cheese produce a softer and more meltable cheese. It is also well known by cheese researchers that 2 cheeses with the same $\mathrm{pH}$ value can have markedly different textural properties. Lucey and Fox (1993) proposed that the total Ca concentration in cheese is not the best indicator or predictor of cheese texture. They suggested that it is the amount of Ca still within casein particles of cheese, that is the insoluble (INSOL) Ca, that plays the key role in modulating cheese texture. One way to support this hypothesis is to demonstrate that there are significant changes in the proportions of Ca in the INSOL and soluble (SOL) phases during Cheddar cheese ripening. If this is found to be the case, then shifts in the mineral equilibrium could be contributing to textural changes during ripening along with the well-known effects of proteolysis.

The earliest attempts to study the composition of the aqueous phase of cheese involved its physical extraction using high pressure; this serum is called juice (Barthel et al., 1928; Sandberg et al., 1930; McDowall and Dolby, 1936). These initial studies used several ripening indi- 
ces, such as the concentration of nitrogen, lactose, and lactic acid contents in the juice, as an estimate of cheese maturation. They were concerned that water extraction methods could alter the physicochemical properties of the cheese. This technique was later used to study the mineral composition of the serum phase (Monib, 1962; Morris et al., 1988; Lucey and Fox, 1993; Lucey et al., 1993a; Salvat-Brunaud et al., 1995; Thierry et al., 1998; Boutrou et al., 1999; Guinee et al., 2000a). The pH values for both cheese and cheese juice are identical. The amount of juice that can be obtained decreases with age for Cheddar (Guinee et al., 2000b), Emmental (Thierry et al., 1998), and Camembert (Boutrou et al., 1999), although it appears that sufficient juice can be obtained from most types of aged cheese to allow for $\mathrm{Ca}$ analysis. Because there is neither dilution nor solubilization of cheese components, only a physical extraction of the aqueous phase, it is an ideal method to study the mineral equilibrium in cheese. Cheese juice has been used to study proteolysis and starter autolysis (e.g., Wilkinson et al., 1994).

Morris et al. (1988) analyzed the juice from a single 1-mo-old Cheddar cheese and reported that $43 \%$ of $\mathrm{Ca}$ was present in the aqueous phase. Lucey and Fox (1993) reported that $\sim 28 \%$ of $\mathrm{Ca}$ was present in the aqueous phase of Cheddar cheese. Guinee et al. (2000a) analyzed a range of commercial Cheddar cheese samples (age and manufacturing conditions not known) and reported that the proportion of SOL Ca ranged from 26 to $44 \%$. It is possible that changes in the proportion of SOL Ca during ripening and due to different manufacturing conditions could be responsible for these differences. Thierry et al. (1998) reported that the proportion of SOL Ca in Emmental cheese ( $30 \%)$ hardly changed during ripening. Guinee et al. (2000a) also analyzed a range of commercial low-moisture Mozzarella cheese samples (age and manufacturing conditions not known) and reported that the proportion of SOL $\mathrm{Ca}$ ranged from 17 to $25 \%$.

Another approach developed by Lucey et al. (1993a, 1993b) and Lucey and Fox (1993) involved the use of acid-base buffering curves to investigate the Ca equilibrium of milk and cheese, but they did not determine if there were changes in the proportions of SOL and INSOL Ca during ripening. During acidification of milk there is a buffering maximum at $\mathrm{pH} \sim 5$ due to solubilization of CCP and the area of this peak reflects the amount of CCP in milk (Lucey et al., 1993b). A similar buffering peak is also found in cheese, and Lucey and Fox (1993) suggested that by comparing the area of the peaks found in milk to those in cheese one should be able to obtain a useful index of the amount of residual CCP present in cheese.
Guo and Kindstedt (1995) used centrifugation to extract some expressible serum to estimate the SOL Ca concentration in the water phase of Mozzarella cheese. A major drawback with this method is that it is only suitable for very high moisture cheeses, like Mozzarella. Even then it can only express some water in very young cheese (i.e., until the end of first week or $10 \mathrm{~d}$ of maturation). For cheeses like Cheddar, no significant quantities of expressible serum can be obtained even if the cheese is ultracentrifuged (e.g., $100,000 \times g$ for $2 \mathrm{~d}$; Morris et al., 1988). Kindstedt and Guo (1997) reported that in directly acidified Mozzarella (acid type and $\mathrm{pH}$ not reported) no expressible serum could be obtained. Metzger et al. (2001a) reported that no expressible serum was obtained with directly acidified Mozzarella that was acidified to $\mathrm{pH} 5.8$ with citric acid, in contrast to acidification with a nonchelating acid (acetic). Naudts and de Vleeschauwer (1959) tried to estimate soluble Ca content of cheese that was present in a water-soluble extract of cheese prepared by dilution of 20 $\mathrm{g}$ of cheese with $100 \mathrm{~mL}$ of water, mixing and filtering off the cheese residue, and determining the concentration of $\mathrm{Ca}$ extracted in the filtrate. Naudts and de Vleeschauwer (1959) reported that in fresh cheese with a $\mathrm{pH} \leq 4.6$, all the $\mathrm{Ca}$ appeared to be SOL. More recently Metzger et al. (2001b) also used a water extract of cheese to estimate the concentration of water-SOL Ca in Mozzarella cheese. However, there are several potential problems with a water-SOL extraction approach, including modification of the Ca equilibrium (between the INSOL and SOL phases) due to the alteration in the $\mathrm{pH}$, ionic strength, and water content of the water/ cheese mixture. It is also possible that any $\mathrm{pH}$ shift and dilution could dissolve any $\mathrm{Ca}$ lactate crystals if they were present. It is not clear whether this method efficiently extracts all the SOL Ca from the cheese matrix in the water, as there is no method to validate the extraction efficiency. In water-soluble extraction methods the high dilution of cheese with water causes a substantial increase in cheese $\mathrm{pH}$ (e.g., with an 11fold dilution, cheese $\mathrm{pH}$ can increase by 0.4 to 0.6 ; Lucey and Lee, unpublished results), which could influence the $\mathrm{Ca}$ equilibrium.

The objective of the present study was to use the acidbase buffering and cheese juice methods to quantify the proportions of SOL and INSOL Ca in Cheddar cheese during maturation.

\section{MATERIALS AND METHODS}

\section{Cheese Manufacturing}

A licensed Wisconsin cheese maker manufactured 4 full-fat, milled-curd Cheddar cheeses at the University of Wisconsin-Madison Dairy Plant over a period of 1 
Table 1. Cheese manufacturing protocol for Cheddar cheese from the four trials.

\begin{tabular}{lcl}
\hline & $\begin{array}{l}\text { Total } \\
\text { elapsed } \\
\text { time }(\mathrm{min})\end{array}$ & $\mathrm{pH}$ \\
\hline Initial milk & 0 & $6.61 \pm 0.06$ \\
Add starter & 0 & $6.61 \pm 0.06$ \\
Add coagulant & 60 & $6.54 \pm 0.05$ \\
Cut & $85 \pm 2$ & $6.52 \pm 0.07$ \\
Drain & $150 \pm 5$ & $6.19 \pm 0.07$ \\
Mill & $238 \pm 32$ & $5.44 \pm 0.01$ \\
Add salt & $252 \pm 33$ & $5.39 \pm 0.05$ \\
\hline
\end{tabular}

yr. The make-procedure for the cheeses from all 4 trials is shown in Table 1. Raw whole milk was pasteurized at $73^{\circ} \mathrm{C}$ for $16 \mathrm{~s}$ and cooled to $32.2^{\circ} \mathrm{C}$. A mixed-strain starter culture consisting of Lactococcus lactis ssp. cremoris, Lactococcus lactis ssp. lactis, and Lactococcus lactis ssp. diacetylactis (DVS 970; Chr. Hansen, Milwaukee, WI) was inoculated into the milk at the rate $45 \mathrm{~mL}$ per $226 \mathrm{~kg}$ of milk and ripened for $60 \mathrm{~min}$. Five minutes before the addition of coagulant, $44.5 \mathrm{~mL}$ of calcium chloride (32\% solution, Rhône-Poulenc, Madison, WI) was added per $226 \mathrm{~kg}$ of milk. Double strength chymosin (Chymostar, Rhodia, Madison, WI) was added at the rate of $9 \mathrm{~mL}$ per $226 \mathrm{~kg}$ of milk. The coagulum was cut with $0.63-\mathrm{cm}$ knives and the curd was given a 5 -min healing time, followed by $10 \mathrm{~min}$ of gentle agitation before heating started. The temperature of the curd-whey mixture was raised from $\sim 32$ to $39^{\circ} \mathrm{C}$ over $30 \mathrm{~min}$. Curd was held at $39^{\circ} \mathrm{C}$ for $30 \mathrm{~min}$ before draining the whey. Curd slabs were cheddared, piled 2 high, and milled at $\mathrm{pH} \sim 5.4$. Curd was salted at the rate of $0.72 \mathrm{~kg}$ per $226 \mathrm{~kg}$ of milk. Curd was packed in 9-kg, Wilson-style hoops and pressed for $4 \mathrm{~h}$ at ambient temperature before vacuum packaging and aging at $7^{\circ} \mathrm{C}$. Two $9-\mathrm{kg}$ blocks of cheese were made during each of the 4 trials. An effort was made to maintain similar moisture contents and $\mathrm{pH}$ at $1 \mathrm{~d}$ in all cheese trials.

\section{Analysis}

All compositional tests were in duplicate. Milk samples were analyzed for total solids (Marshall, 1992), fat (Marshall, 1992), protein (IDF, 1986), and casein content (IDF, 1964). Cheese samples were analyzed for moisture (IDF, 1982), fat (Marshall, 1992), salt by Corning Salt Analyzer (Marshall, 1992), pH by quinhydrone method (Marshall, 1992), protein (total percentage of $\mathrm{N} \times 6.38$ ) by Kjeldahl (IDF, 1986). Cheese juice samples were analyzed for total solids (IDF, 1982) and $\mathrm{pH}$ by inserting a $\mathrm{pH}$ probe $(\mathrm{pH}$ meter $420 \mathrm{~A}$, Orion Research Inc., Beverly, MA).

\section{Titration Method}

The titration procedure was based on the method developed by Lucey et al. (1993a) and Lucey and Fox (1993). At least 4 titrations were performed for each cheese sample. Cheddar cheese homogenates were prepared for titration by mixing $8 \mathrm{~g}$ of grated cheese with $40 \mathrm{~mL}$ of distilled water at $50^{\circ} \mathrm{C}$ in a blender (Waring Commercial with a MC2 mini-container, New Hartford, CT) and homogenized at high speed for $1 \mathrm{~min}$. The cheese slurry was then homogenized at $19,000 \mathrm{~s}^{-1}$ for 3 min in an Ultra-Turrax homogenizer (T25 Basic with S25N-18G dispersing element, IKA Works, Inc., Wilmington, NC). The homogenized mixture was then cooled to $25^{\circ} \mathrm{C}$ before titration.

A computer-controlled, automated $\mathrm{pH}$ titration system (Mettler Toledo DL50 Titrator, Schwerzenbach, Switzerland) was used for acid-based titration of milk and cheese samples. The $\mathrm{pH}$ electrode (Mettler Toledo DG115 SE, Greifensee, Switzerland) was calibrated with the following $\mathrm{pH}$ buffers: 4.0, 7.0, and 10.0 (Fisher Scientific, Fair Lawn, NJ). The range of the slope of the electrode at $25^{\circ} \mathrm{C}$ was maintained consistently between 56.5 to $58.5 \mathrm{mV} / \mathrm{pH}$ (theoretical slope $=58.0 \mathrm{mV} / \mathrm{pH}$ ) and was checked on a daily basis. Cheese homogenates and milk samples were titrated from the initial $\mathrm{pH}$ of cheese $(\sim 5.1)$ and milk ( 6.6) to $\mathrm{pH} 3.0$ with $0.5 \mathrm{M} \mathrm{HCl}$ and then back titrated to $\mathrm{pH} 9.0$ with $0.5 \mathrm{M} \mathrm{NaOH}$. Titrants were added in 0.1 -mL increments at 30 -s intervals to allow for equilibrium of titrant and homogenate. Titrations were carried out at $\sim 25^{\circ} \mathrm{C}$.

Change in $\mathrm{pH}(\mathrm{dpH})$, resulting from the addition of each increment of acid or base, and the volume of titrant used in the titration were recorded by the titrator and exported into a Microsoft Excel spreadsheet. Buffering indices $(\mathrm{dB} / \mathrm{dpH})$ were calculated according to Van Slyke (1922) as follows:

$\frac{d B}{d p H}=\frac{m l \text { of acid or base added } \times \text { normality of acid or base }}{\text { volume of sample } \times p H \text { change produced }}$

Buffering curves were prepared by plotting buffering index as a function of $\mathrm{pH}$. The change in total volume of sample due to the addition of acid or alkali during the titration was taken into account in the buffering index calculations.

A software program was developed in MATLAB (Version 5.3, The MathWorks Inc., Natick, MA) to calculate the area under each buffering curve. The "Trapezoidal" rule numerical integration method (Potter and Goldberg, 1987) was used to calculate the areas under the buffering curves. The difference in area between the forward and back titration buffering curves was calculated for milk and cheese samples as shown in Figure 


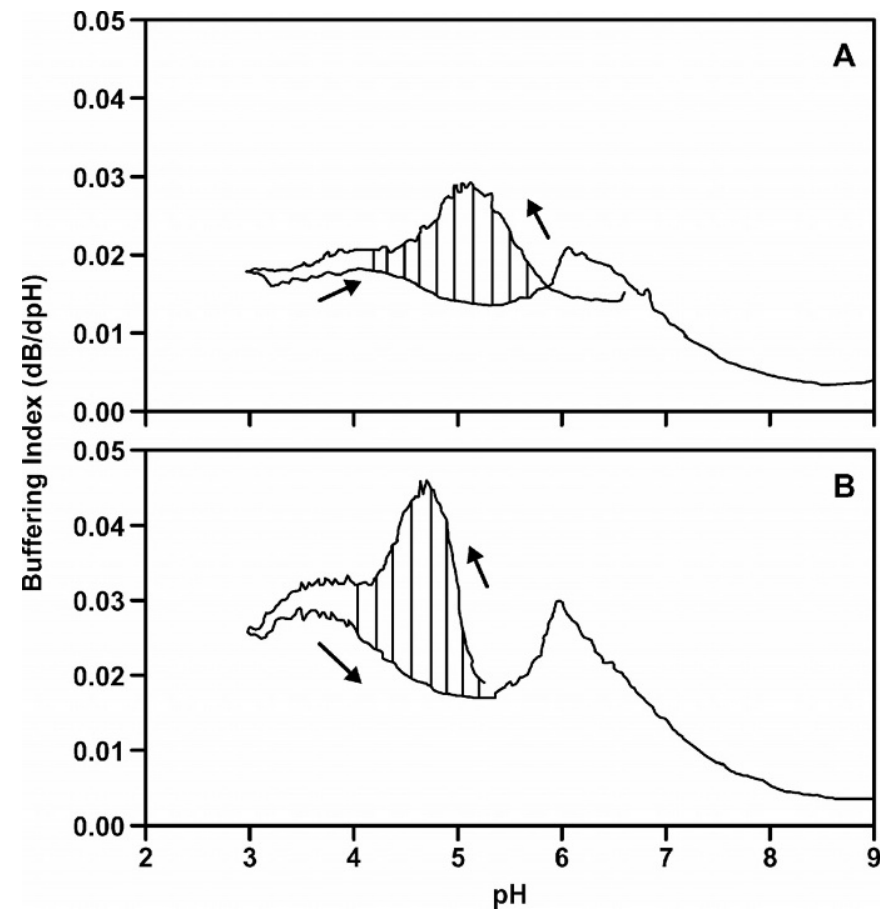

Figure 1. Buffering curves of milk (A) and Cheddar cheese (B) titrated from initial $\mathrm{pH}$ to $\mathrm{pH} 3.0$ with $0.5 \mathrm{~N} \mathrm{HCl}$ and then back titrated to $\mathrm{pH} 9.0$ with $0.5 \mathrm{~N} \mathrm{NaOH}$. Hatched area represents the buffering due to colloidal calcium phosphate. Arrows indicate the direction of the titration.

1. It was decided to integrate the milk and cheese curves between the $\mathrm{pH}$ limits of $\sim 5.8$ to 4.1 and $\sim 5.1$ to 4.0 , respectively. The lower $\mathrm{pH}$ limit was chosen based on the observation that at $\mathrm{pH} \sim 4.0$ the buffering curve (with acid) flattened, indicating the likely end of the buffering effect caused by the solubilization of CCP. The calculations used to estimate the percentage of INSOL $\mathrm{Ca}$ in cheese by the titration method are as follows:

$$
\begin{gathered}
\text { INSOL Ca content }(\mathrm{mg} / 100 \mathrm{~g})= \\
\left(\frac{m g \text { INSOL Ca per } 100 \mathrm{~g} \text { milk }}{A_{M}}\right) \times\left(\mathrm{A}_{C} \times \mathrm{D}\right)
\end{gathered}
$$

$$
\% \text { INSOL Ca in cheese }=
$$

$\left(\frac{\text { INSOL Ca content }(\mathrm{mg} / 100 \mathrm{~g} \text { cheese })}{\text { Total Ca content of cheese }(\mathrm{mg} / 100 \mathrm{~g} \text { cheese })}\right) \times 100$

where $A_{m}$ and $A_{c}$ are the residual areas when the back (titration with base) buffering curve is subtracted from the initial or forward (acidification) buffering curve for milk and cheese, respectively; INSOL $\mathrm{Ca}$ in milk $(\mathrm{mg} /$
$100 \mathrm{~g})=$ total $\mathrm{Ca}$ in milk $(\mathrm{mg} / 100 \mathrm{~g})-\mathrm{SOL} \mathrm{Ca}$ in milk (mg/100 g); SOL Ca in milk was defined as Ca content of rennet whey $\times$ correction factor for whey (Davies and White, 1960; $D$ is the dilution factor, which was 6 as 8 $\mathrm{g}$ of cheese were mixed with $40 \mathrm{~mL}$ of water; and total Ca content of cheese $(\mathrm{mg} / 100 \mathrm{~g})$ was determined using atomic absorption spectroscopy.

\section{Cheese Juice Method}

Extraction of cheese juice. The cheese juice procedure was based on the method developed by Morris et al. (1988) and Lucey et al. (1993a). A stainless steel mold was designed and fabricated at the University of Wisconsin-Madison, Physical Plant workshop. It consisted of a collection vessel, perforated vessel, an outer cover, and a heavy ram. Freshly grated cheese ( $800 \mathrm{~g}$ ) was thoroughly mixed with $1000 \mathrm{~g}$ of washed sea sand (Fisher Scientific) and placed in the stainless steel mold lined with cheese cloth (Pyrex Heavy Duty Cheesecloth, Robinson Knife Company, Buffalo, NY). The cheesesand mixture was subjected to high pressure using a hydraulic press (Fred S. Carver, Inc., Summit, NJ) at room temperature. Pressure was increased gradually over $1 \mathrm{~h}$ up to a maximum of $\sim 8 \mathrm{MPa}$, and liquid fat and juice were collected in a graduated cylinder until all flow of liquid stopped at $\sim 3 \mathrm{~h}$. The liquid fat and juice were transferred to a beaker. There were separate layers of liquid fat and juice. The beaker was stored at $5^{\circ} \mathrm{C}$ for 15 min to allow the liquid fat to solidify. A hole was made in the solid fat layer using a spatula, and the juice was decanted through the opening. The juice was then centrifuged at $\sim 2000 \times g$ for $10 \mathrm{~min}$ at $4^{\circ} \mathrm{C}$ (CR3i Centrifuge, Jouan, Winchester, VA) to remove any extraneous fat and curd particles.

Calcium analysis. The cheese, juice, and milk were analyzed for Ca content using flame atomic absorption spectroscopy at the Department of Biochemistry, University of Wisconsin-Madison by the method described by IDF (1992). The atomic absorption spectrometer (Perkin Elmer Atomic Absorption Spectrometer 3110, Norwalk, CT), fitted with a Ca lamp (6 mA Ca lamp, Fisher Scientific, England), was calibrated with reference standards $(2.5,5.0$, and $10.0 \mathrm{mg} \mathrm{Ca} / \mathrm{mL})$ prepared from Ca reference solution (SC191-100, Fisher Scientific). All samples contained 10\% (vol/vol) lanthanum chloride solution.

Calculation of percentage INSOL Ca of cheese by the cheese juice method. The Ca content in juice was used to estimate the percentage SOL Ca in cheese by assuming that whatever SOL components were present in the juice were also present in the moisture phase of cheese at a similar concentration. 
Table 2. Composition of milks and Cheddar cheeses (means \pm standard deviation).

\begin{tabular}{lr}
\hline Item & \\
\hline Milk & \\
CP, $\%$ & $3.2 \pm 0.19$ \\
Casein, \% & $2.46 \pm 0.15$ \\
Fat, $\%$ & $3.50 \pm 0.18$ \\
Total Ca, mg/100 g & $143 \pm 15$ \\
Soluble Ca, mg/100 g & $61 \pm 11$ \\
Cheese & \\
Protein, \% & $26.2 \pm 1.7$ \\
Moisture, \% & $38.6 \pm 0.6$ \\
Fat, \% & $33.4 \pm 1.1$ \\
Salt, $\%$ & $1.72 \pm 0.3$ \\
Salt-in-moisture, \% & $4.46 \pm 0.8$ \\
pH at 1 d & $5.06 \pm 0.01$ \\
pH at 12 wk & $5.14 \pm 0.07$ \\
Total Ca, mg/100 g & $833 \pm 25$ \\
Moisture content of juice at 1 d, $\%$ & $88.9 \pm 0.4$ \\
Moisture content of juice at 12 wk, $\%$ & $78.2 \pm 1.3$ \\
Ca content of juice at 1 d, mg/ 100 g & $644 \pm 50$ \\
Ca content of juice at 12 wk, mg/100 g & $776 \pm 15$ \\
INSOL Ca at 1 d by juice method, ${ }^{1} \%$ & $70 \pm 2.6$ \\
INSOL Ca at 1 d by titration method, ${ }^{1} \%$ & $76 \pm 5.5$ \\
INSOL Ca at 12 wk by juice method, ${ }^{1} \%$ & $58 \pm 0.1$ \\
INSOL Ca at 12 wk by titration method, ${ }^{1} \%$ & $58 \pm 4.6$ \\
\hline
\end{tabular}

${ }^{1}$ Insoluble Ca content as a \% of total Ca in cheese.

One complication that was considered was that the cheese juice may only reflect the "free" water portion or serum phase and not the "bound" water (as this would not be expressed by the high pressure treatment and is not available as a solvent). In cheese, approximately $0.125 \mathrm{~g}$ of water has been estimated to bind to $1 \mathrm{~g}$ of protein in cheese (Geurts et al., 1974). The amount of "bound water" in cheese was subtracted from the total moisture content to estimate the "free moisture" content. The actual situation in cheese is probably more complicated, as both shifts in the mineral equilibrium (Lucey et al., 2003) and the creation of new ionic groups as a result of proteolysis (Creamer and Olson, 1982) alter the state of water in Cheddar cheese during ripening.

The percentage of INSOL Ca in cheese was otherwise determined as described by Morris et al. (1988):

$$
\% \text { INSOL } C a=100\left(\frac{m_{x}}{H}-\frac{m_{\mathrm{x}}^{\prime}}{H^{\prime}}\right) \frac{H}{m_{x}}
$$

where $m_{x}$ and $m_{x}{ }^{\prime}$ are the concentration of Ca in cheese and juice, respectively, and $H$ and $H^{\prime}$ are the number of kilograms of $\mathrm{H}_{2} \mathrm{O}$ per kilogram of cheese and juice, respectively.

\section{Statistical Analysis}

Changes in INSOL Ca content of cheese were analyzed using a split-plot design with treatment (i.e.,
Table 3. Mean squares, probabilities and degrees of freedom (df) for factors that may influence the INSOL ${ }^{1} \mathrm{Ca}$ content of cheese

\begin{tabular}{lccl}
\hline Factor & df & $\begin{array}{l}\text { Mean } \\
\text { squares }\end{array}$ & $P$-value \\
\hline Whole-plot & & & \\
$\quad$ Trial & 3 & 64.179 & 0.36 \\
$\quad$ Method & & 0.151 & 0.95 \\
$\quad$ Error & 1 & 41.767 & - \\
Subplot & 3 & 258.500 & $0.0001^{* *}$ \\
$\quad$ Week & 4 & 22.748 & $0.0008^{* *}$ \\
$\quad$ Method $\times$ week & 4 & 3.308 & - \\
$\quad$ Error & 24 & & \\
$\mathrm{R}^{2}$ & 0.94 & \\
\hline${ }^{1}$ Insoluble Ca content as a \% of total Ca in cheese. \\
$\quad{ }^{2}$ Methods used were acid-base titration and cheese juice. \\
$\quad$ *Statistically significant $(P<0.01)$.
\end{tabular}

method used for determining the INSOL Ca content) as the whole plot factor. For the whole plot factor, method was analyzed as a class variable and the trial number was blocked. For the subplot factor, week and week $\times$ method were analyzed as discontinuous variables. If the $F$-test for the effect (method and week) were significant $(P<0.05)$, the treatment means were analyzed by the least significant difference test $(P<$ 0.05). The PROC MIXED program of SAS (SAS, 2001) was utilized for the analysis.

\section{RESULTS AND DISCUSSION}

The compositions of cheesemilks and Cheddar cheeses were similar with some small variation since these 4 trials were conducted over a 1-yr period (Table 2 ). The moisture and $\mathrm{pH}$ values in the cheeses were similar. There was a slight increase in $\mathrm{pH}$ during the 12 -wk ripening period, which is similar to what we usually observe for Cheddar cheese. The total Ca content of the cheeses was in the range expected for Cheddar cheese (Lucey and Fox, 1993).

The acid-base buffering properties of milk and cheese are shown in Figure 1. When milk was acidified with $\mathrm{HCl}$, there was a buffering peak at $\mathrm{pH} \sim 5$, in agreement with the results of Lucey et al. (1993b). This peak is due to the solubilization of CCP leading to the formation of phosphate ions, which combine with $\mathrm{H}^{+}$, resulting in buffering (Lucey et al., 1993b). During back titration with $\mathrm{NaOH}$, the buffering peak at $\mathrm{pH} 5$ was absent and increased buffering occurred around $\mathrm{pH} 6$, in agreement with the results of Lucey et al. (1993b). The peak during back titration with base was probably due to the formation of $\mathrm{Ca}$ phosphate (Lucey et al., 1993b). The area between the forward and back titrations was used as an index of the concentration of residual CCP in milk as proposed by Lucey et al. (1993b). When cheese was titrated with $\mathrm{HCl}$, a buffering peak was observed at $\mathrm{pH}$ 

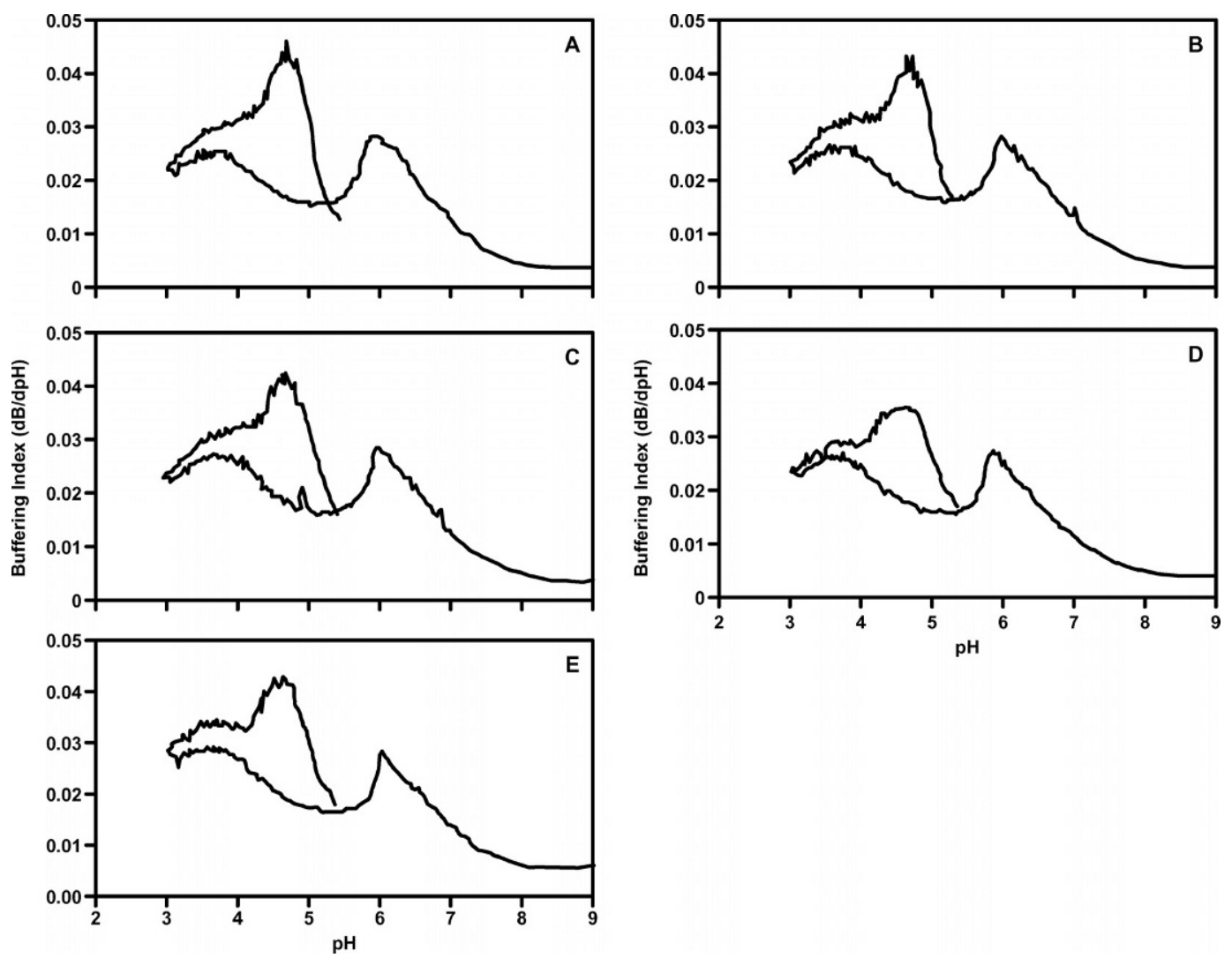

Figure 2. Buffering curves for Cheddar cheese at age 0 (a), 1 (b), 2 (c), 4 (d), and 12 (e) wk titrated from initial $\mathrm{pH}$ to $\mathrm{pH} 3.0$ with 0.5 $N \mathrm{HCl}$ and then back titrated to $\mathrm{pH} 9.0$ with $0.5 \mathrm{~N} \mathrm{NaOH}$.

$\sim 4.8$, which was presumably residual CCP (Lucey and Fox, 1993). During back titration, the peak at $\mathrm{pH} 5$ was absent and a buffering peak was observed at $\mathrm{pH} \sim 6$, which was similar to the titration curves of milk. The lower $\mathrm{pH}$ for the buffering peak during the acidification of cheese presumably reflects an alteration in the solubility of CCP in the cheese environment (i.e., higher solids, close packing, and high ionic strength).

During ripening, the area of this buffering peak at $\mathrm{pH}$ $\sim 5$ decreased, especially during the first $3 \mathrm{wk}$ (Figure 2 ), indicating that there was a decrease in the INSOL Ca content. This indicated that during cheese ripening there was conversion of INSOL to SOL Ca. The percentage INSOL $\mathrm{Ca}$ as a percentage of total $\mathrm{Ca}$ in cheese decreased during ripening with both methods (Figure $3)$. The INSOL Ca content was significantly affected by week and method $\times$ week $(P<0.01)$ but not by method or trial (Table 3). There were no significant differences in the INSOL Ca content of cheeses between the 2 methods at any ripening time (Table 4). Both the titration and juice methods illustrated that the major changes in Ca equilibrium took place during the first $4 \mathrm{wk}$.

Guo and Kindstedt (1995) and Guo et al. (1997) reported that the concentration of $\mathrm{Ca}$ in centrifugally ex- pressible serum from low moisture Mozzarella increased during the first week. We recalculated their data, assuming that expressible serum was equivalent to juice and that the moisture content of the serum was $\sim 88 \%$. We estimate that 2 -d cheese contained $\sim 75$ to $80 \%$ INSOL $\mathrm{Ca}$, and there was an increase in the amount of SOL Ca during storage but no expressible serum could be obtained after about 1 wk. Metzger et al. (2001b) using a water extraction method reported that in lowfat Mozzarella the concentration of $\mathrm{Ca}$ in the extract was stable during ripening but increased if cheese was made from preacidified milk. In Camembert cheese there was an increase in the $\mathrm{Ca}$ concentration in juice for first 4 to $6 \mathrm{~d}$ but thereafter the Ca content decreased, which paralleled the initial decrease in $\mathrm{pH}$ caused by the fermentation of residual lactose. This was followed by the subsequent increase in $\mathrm{pH}$ of the outer layer due to activity of the surface mold (Boutrou et al., 1999). The high $\mathrm{pH}$ at the surface of Camembert cheese leads to the precipitation of various $\mathrm{Ca}$ salts (Lucey and Fox, 1993), which presumably causes a reduction in the $\mathrm{Ca}$ content in the center as more $\mathrm{Ca}$ is drawn to the surface. 
Table 4. INSOL ${ }^{1} \mathrm{Ca}$ content of cheese during ripening determined by two different methods. ${ }^{2}$

\begin{tabular}{llll}
\hline & \multicolumn{2}{c}{ Method } & \\
\cline { 2 - 3 } Age (weeks) & Juice & Titration & SEM \\
\hline 0 & $69.72^{\mathrm{a}}$ & $75.70^{\mathrm{a}}$ & 1.81 \\
1 & $64.16^{\mathrm{a}}$ & $69.27^{\mathrm{a}}$ & 1.81 \\
2 & $63.70^{\mathrm{a}}$ & $63.25^{\mathrm{a}}$ & 1.81 \\
4 & $61.77^{\mathrm{a}}$ & $60.75^{\mathrm{a}}$ & 1.81 \\
12 & $57.87^{\mathrm{a}}$ & $57.65^{\mathrm{a}}$ & 1.81 \\
\hline
\end{tabular}

${ }^{a}$ Means within the same row not sharing a common superscript are different $(P<0.05)$

${ }^{1}$ Insoluble Ca content as a $\%$ of total $\mathrm{Ca}$ in cheese.

${ }^{2}$ Methods used were acid-base titration and cheese juice.

The results of Morris et al. (1988), Lucey and Fox (1993), and Guinee et al. (2000a) suggest that Cheddar cheese contains a substantial proportion of SOL Ca (i.e., between 26 to $43 \%$ of total $\mathrm{Ca}$ ). In the present study the proportions of SOL Ca in Cheddar cheese were 24 to $30 \%$ and $\sim 42 \%$ at $d 1$ and wk 12 , respectively. There was no previous study of age-related changes in the $\mathrm{Ca}$ equilibrium of Cheddar cheese. The proportions of SOL reported in the present study closely agree with the range of values previously reported for Cheddar cheese. Morris et al. (1988) considered that as the $\mathrm{pH}$ drops during cheese making, all the CCP in milk dissolves and that in curd a supersaturated solution is formed, which then undergoes nucleation with the formation of various types of $\mathrm{Ca}$ crystals (e.g., lactate, phosphate, and citrate). The great similarities between the acidbase buffering curves of milk and cheese (Figure 1) suggest that much of the CCP present in milk still remains in cheese despite the low $\mathrm{pH}$.

An advantage for the titration method is the unique buffering peak for CCP, which would not be sensitive to possible complications such as the formation of INSOL Ca lactate (or any other Ca crystals). However, no Ca lactate crystals were observed in our cheeses, and they are more often observed in aged Cheddar or in cheeses that have very high levels of both $\mathrm{Ca}$ and lactic acid. Another advantage of the titration method is the ability to test various parts of the cheese (e.g., interior, which could be useful in a cheese such as Camembert, where there is a Ca gradient between the surface and the interior). The large sample size required for the juice method makes it more cumbersome for this type of investigation. It was considered that the titration method may give lower values for the INSOL Ca content due to the dilution of the cheese during preparation of the cheese homogenate, which may solubilize some CCP. On the other hand, there was a slight increase in $\mathrm{pH}$ when cheese was diluted with distilled water, which should encourage a slightly higher value for INSOL Ca, obtained from titration method in comparison to the

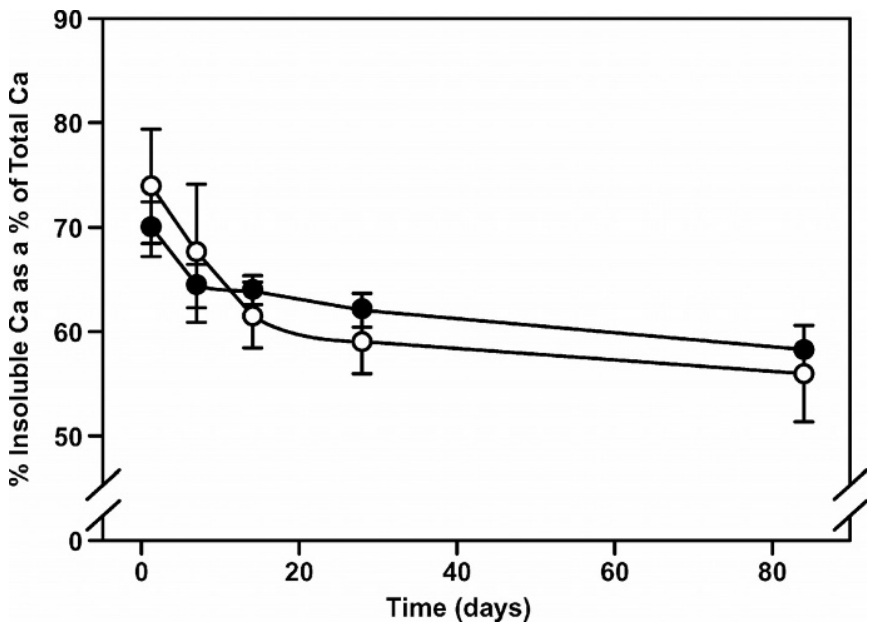

Figure 3. Changes in the \% insoluble Ca content (expressed as a $\%$ of total cheese $\mathrm{Ca}$ ) as a function of ripening time in Cheddar cheese determined by titration $(\bigcirc)$ and cheese juice $(-)$ methods. Standard deviations $(n=4)$ for each time point are indicated by the error bars.

juice method. In this study, there were no significant differences between the 2 methods (Table 4).

The $\mathrm{pH}$ measurements of cheese indicated that there was a slight increase from $\mathrm{pH} 5.06$ to 5.14 during ripening (Table 1). It is expected that any increase in $\mathrm{pH}$ should have encouraged the formation of more INSOL $\mathrm{Ca}$ as it is well known that Ca phosphate becomes more INSOL at higher $\mathrm{pH}$ values. Thus, the slight increase in $\mathrm{pH}$ was not responsible for the time-dependent equilibrium changes observed for INSOL $\mathrm{Ca}$ in cheese. Cheeses had an average S/M level of $\sim 4.4 \%$, indicating that the fermentation of lactose by the starter culture was likely to be virtually complete in the first few weeks of ripening (Fox et al., 2000). The observed increase in $\mathrm{pH}$ may be caused by the slow solubilization of CCP, as an upward drift in milk $\mathrm{pH}$ can occur when milk is acidified to $\mathrm{pH} \sim 5$ (Singh et al., 1997). The strong buffering by CCP at low $\mathrm{pH}(\sim 5.0)$ of cheese (Lucey and Fox, 1993) resists the further $\mathrm{pH}$ decrease that is expected to occur due to the ongoing production of lactic acid by the starter culture. Thus, the changes in cheese $\mathrm{pH}$ observed during the first few weeks of Cheddar cheese ripening may be caused by 2 main factors (Figure 4): biochemical changes (metabolism of a relatively large amount of residual lactose $\sim 10 \mathrm{~g} / \mathrm{kg}$ of cheese to lactic acid) and chemical equilibrium changes (conversion of INSOL to SOL Ca).

It has long been known that there is greater curd demineralization when more of the acid is developed in the vat (i.e., by preacidification of milk, draining at a low pH value) (Lucey and Fox, 1993). It is also well recognized that in direct acid cheeses there is greater demineralization compared with a cultured product 


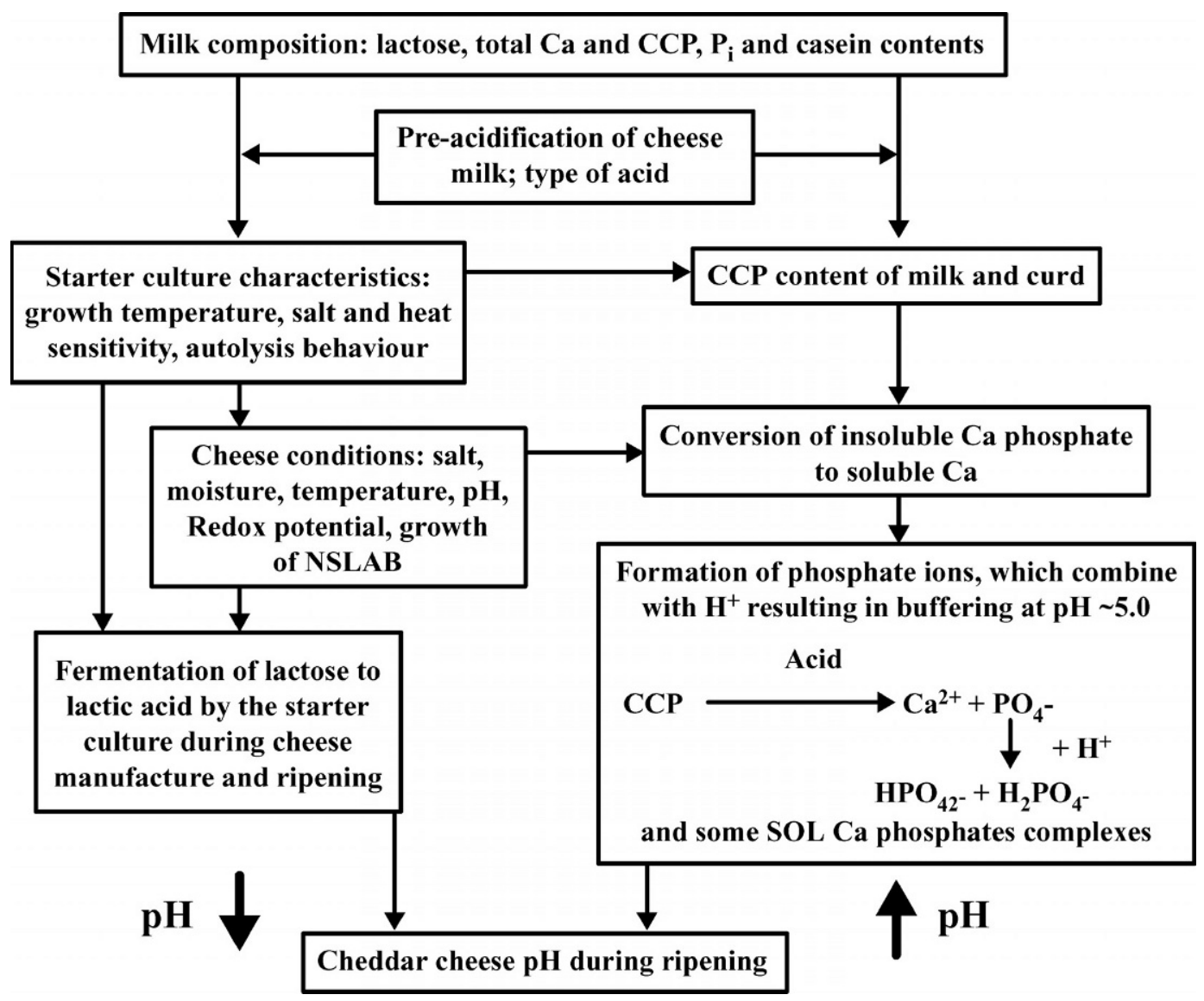

Figure 4. Schematic diagram showing the possible relationship between the metabolism of lactose, solubilization of colloidal Ca phosphate (CCP) and $\mathrm{pH}$ changes during Cheddar cheese ripening.

even at the same $\mathrm{pH}$ value (Keller et al., 1974). We hypothesize that CCP is less soluble in curd/cheese compared with milk due to the decreased moisture content of the curd (Lucey et al., 2003); the high SOL Ca levels in the cheese serum/juice, and possibly the high casein content of cheese. This area needs to be investigated to understand which factor(s) is responsible. Solubilization of residual CCP occurred predominately during the first $4 \mathrm{wk}$ of ripening with only small changes occurring slowly thereafter (Figure 3). We presume that this reflects the slow attainment of a "pseudoequilibrium"; the Ca phosphate in milk (and cheese) is not in true equilibrium due to the presence of inhibitors, such as casein (Walstra et al., 1999), as well as other factors, such as the high ionic strength of curd.

\section{CONCLUSIONS}

The cheese juice and titration methods can be used to quantify the proportions of SOL and INSOL $\mathrm{Ca}$ in Cheddar cheese during ripening. The majority of $\mathrm{Ca}$ present in Cheddar cheese is in an INSOL form similar to the CCP of milk. There was a decrease in the INSOL Ca content during ripening, reflecting the slow solubilization of some of the residual CCP present in cheese. There were no significant differences between the INSOL Ca content of cheese determined by the 2 methods. Changes in the amount of INSOL Ca in Cheddar occur concomitantly with several biochemical events, such as proteolysis, and both probably contribute to cheese textural changes during ripening. The net result of a decrease in the INSOL Ca content should be a weakening of cheese structure and an increase in meltability, if all other factors are unchanged. These methods are useful techniques to study the role of $\mathrm{Ca}$ in cheese texture and the impact of alterations to the cheesemaking procedures (e.g., preacidification) on functionality.

\section{ACKNOWLEDGMENTS}

The authors appreciate the funding of Dairy Management, Inc. and the Wisconsin Center for Dairy Research. The authors thank John Jaeggi and Bill Hoesly of the Wisconsin Center for Dairy Research for cheese- 
making, workers in the University of Wisconsin-Madison Dairy plant for milk processing, and Jongwoo Choi for assistance with statistical analysis.

\section{REFERENCES}

Barthel, C., E. Sandberg, and E. Hagland. 1928. Recherches sur la présure dans les fromages. Lait 8:762-768.

Boutrou, R., F. Gaucheron, M. Piot, F. Michel, J.-L. Maubois, and J. Léonil. 1999. Changes in the composition of juice expressed from Camembert cheese during ripening. Lait 79:503-513.

Creamer, L. K., and N. F. Olson. 1982. Rheological evaluation of maturing Cheddar cheese. J. Food Sci. 47:631-636, 646.

Davies, D. T., and J. C. D. White. 1960. The use of ultrafiltration and dialysis in isolating the aqueous phase of milk and in determining the partition of constituents between the aqueous and dispersed phases. J. Dairy Res. 27:171-190.

Fox, P. F., T. P. Guinee, T. M. Cogan, and P. L. H. McSweeney. 2000. Fundamentals of Cheese Science. Aspen Publishers, Inc., Gaithersburg, MD.

Keller, B., N. F. Olson, and T. Richardson. 1974. Mineral retention and rheological properties of Mozzarella cheese made by direct acidification. J. Dairy Sci. 57:174-179.

Geurts, T. J., P. Walstra, and H. Mulder. 1974. Water binding to milk protein, with particular reference to cheese. Neth. Milk Dairy J. 28:46-72.

Guinee, T. P., M. A. E. Auty, and M. A. Fenelon. 2000a. The effect of fat content on the rheology, microstructure and heat-induced functional characteristics of Cheddar cheese. Int. Dairy J. $10: 277-288$.

Guinee, T. P., D. Harrington, M. O'Corcoran, E. O. Mulholland, and C. Mullins. 2000b. The compositional and functional properties of commercial mozzarella, cheddar and analogue cheeses. Int. J. Dairy Technol. 53:51-56.

Guo, M. R., and P. S. Kindstedt, P.S. 1995. Age related changes in the water phase of Mozzarella cheese. J. Dairy Sci. 78:2099-2107.

Guo, M. R., J. A. Gilmore, and P. S. Kindstedt. 1997. Effect of sodium chloride on the serum phase of Mozzarella cheese. J. Dairy Sci. 80:3092-3098.

Holt, C. 1992. Structure and stability of bovine casein micelles. Adv. Protein Chem. 43:63-151.

Horne, D. S. 1998. Casein interactions: Casting light on the Black Boxes, the structure in dairy products. Int. Dairy J. 8:171-177.

IDF. 1964. International standard for the determination of the casein content of milk. 29:1964. International Dairy Federation, Brussels, Belgium.

IDF. 1982. Determination of total solids content of cheese and processed cheese. 4A:1982. International Dairy Federation, Brussels, Belgium.

IDF. 1986. Determination of nitrogen content (Kjeldahl method) and calculation of crude protein content. 20A:1986. International Dairy Federation, Brussels, Belgium.

IDF. 1992. Determination of calcium content of milk and dried milkflame atomic absorption spectrometric method. 154:1992. International Dairy Federation, Brussels, Belgium.

Kindstedt, P. S., and M. R. Guo. 1997. Chemically-acidified pizza cheese production and functionality. Pages 24-30 in Proc. 5th Cheese Symposium, Teagasc, Dublin, Ireland.

Lucey, J. A., and P. F. Fox. 1993. Importance of calcium and phosphate in cheese manufacture: A review. J. Dairy Sci. 76:1714-1724.
Lucey, J. A., C. Gorry, and P. F. Fox. 1993a. Changes in the acidbase buffering curves during the ripening of Emmental cheese. Milchwissenschaft 48:183-186.

Lucey, J. A., B. Hauth, C. Gorry, and P. F. Fox. 1993b. The acid-base buffering properties of milk. Milchwissenschaft 48:268-272.

Lucey, J. A., M. E. Johnson, and D. S. Horne. 2003. Perspectives on the basis of the rheology and texture properties of cheese. J. Dairy Sci. 86:2725-2743.

Marshall, R. T. 1992. Standard Methods for the Examination of Dairy Products. 16th ed. American Public Health Association, Washington, DC.

McDowall, F. H., and R. M. Dolby. 1936. Studies on the chemistry of Cheddar cheese making. IV. Lactose and lactic acid in whey and curd; the presence of bound water in curd; the existence of a Donnan equilibrium between curd and whey; and the rate of penetration of salt into curd. J. Dairy Res. 7:156-175.

Metzger, L. E., D. M. Barbano, P. S. Kindstedt, and M. R. Guo. 2001a. Effect of milk preacidification on low fat Mozzarella cheese: II. Chemical and functional properties during storage. J. Dairy Sci. 84:1348-1356.

Metzger, L. E., D. M. Barbano, and P. S. Kindstedt. 2001b. Effect of milk preacidification on low fat Mozzarella cheese: III. Post-melt chewiness and whiteness. J. Dairy Sci. 84:1357-1366.

Morris, H. A., C. Holt, B. E. Brooker, J. M. Banks, and W. Manson. 1988. Inorganic constituents of cheese: analysis of juice from onemonth old Cheddar cheese and the use of light and electron microscopy to characterize the crystalline phases. J. Dairy Res. 55:255-268.

Monib, A. M. M. F. 1962. The calcium-paracaseinate-phosphate complex under conditions similar to those in cheese. Meded. Landbouwhogesch. Wageningen 62:1-76.

Naudts, M., and A. de Vleeschauwer. 1959. Pages 995-1005 in Recherches sur la teneur en calcium du fromage frais. World Congr. Agric. Res. Int. Confed. Tech. Agric., Rome.

Potter, M. C., and J. Goldberg. 1987. Mathematical Methods. 2nd ed. Prentice-Hall, Inc., Englewood Cliffs, NJ.

Salvat-Brunaud, D., J. L. Maubois, Y. Le Graët, M. Piot, M. B. Maillard, C. Corre, and A. Thierry. 1995. Extraction et analyse de la phase aqueuse de l'emmental à 4 stades d'affinage. Lait 75:239-249.

Sandberg, E., E. Hagland, and C. Barthel. 1930. L'analyse du jus de fromage comme moyen de déterminer le degré de la maturation. Lait 10:1-21.

SAS Institute Inc. 2001. Release 8.2. Cary, NC.

Singh, H., O. J. McCarthy, and J. A. Lucey. 1997. Physico-chemical properties of milk. Pages 469-518 in Advanced Dairy Chemistry, Volume 3, Lactose, Water, Salts and Vitamins. 2nd ed. P. F. Fox, ed. Chapman \& Hall, London, UK.

Thierry, A., D. Salvant-Brunard, M.-M. Madec, F. Michel, and J.-L. Maubois. 1998. Affinage de l'emmental: dynamique des populations bactérienne et évolution de la composition de la phase aquese. Lait 78:521-542.

Van Slyke, D. D. 1922. On the measurement of buffer value and on the relationship of buffer value to the dissociation constant of the buffer and the concentration and reaction of the buffer solution. J. Biol. Chem. 52:525-571.

Walstra, P., T. J. Geurts, A. Noomen, A. Jellema, and M. A. J. S. van Boekel. 1999. Dairy Technology: Principles of Milk, Properties and Processes. Marcel Dekker, Inc. New York, NY.

Wilkinson, M. G., T. P. Guinee, and P. F. Fox. 1994. Factors which may influence the determination of autolysis of starter bacteria during Cheddar cheese ripening. Int. Dairy J. 4:141-160. 